\title{
Investigation of Wear Behavior of Particle Reinforced AL/B4C Composites under Different Sintering Conditions
}

\author{
İsmail Topcu
}

\begin{abstract}
In this study, the effects of different sintering conditions of boron carbide reinforced to aluminum matrix powder on microstructure, density and wear resistance by a mechanical alloying method were researched. Powders produced by mechanical alloying for eight hours at the atrial shaft were compressed with a cold isostatic press die under $350 \mathrm{MPa}$ to obtain cylindrical composite specimens. The raw samples were sintered in high purity argon at $600,625,650{ }^{\circ} \mathrm{C}$ for 90 minutes. The wear behavior of the Al/ $\mathrm{B}_{4} \mathrm{C}$ metal matrix composite was studied using a pin-on-disk wear tester. Under favorable conditions, it has been observed that reinforced boron carbide wear can be reduced by more than two decades. Various investigations have been made to relate this improved wear performance to reinforcement ratios. Aluminum abrasion test results showed that different types of abrasion occurred and that the abrasion resistance was increased by the change of the bubble rate. In the experimental studies that were carried out, it was observed that wear resistance increased with the proportion of boron carbide reinforced directly by the weight, and especially with a $15 \% \mathrm{~B}_{4} \mathrm{C}$ ratio depending on the increased reinforcement ratio.
\end{abstract}

Keywords: $\mathrm{B}_{4} \mathrm{C}$; mechanical properties; sintering; wear

\section{INTRODUCTION}

Powder metallurgy $(\mathrm{P} / \mathrm{M})$ is a highly developed production method geared towards obtaining clearly shaped products by mixing alloyed powders prepared beforehand (mechanical alloying). The $\mathrm{P} / \mathrm{M}$ process is a highly costeffective and unique part production method in the production of simple or complicated parts in final dimensions. Metal matrix composites (MMC) consist of at least one metal and one reinforcement. In order to reach necessities that cannot be met with single-component materials and expected properties, materials such as fibers, intermetallic particles, compounds, oxides, carbides or nitrides are continuously used [1-4]. Today, MMC composite production has become more available by using various reinforcement particles with the process of liquid-phase sintering. The most important factor behind the development of MMC has become not only good mechanical and physical characteristics but also high-temperature capabilities increased by reinforcements $[5,6]$. In addition to the improved mechanical properties, properties such as the thermal expansion coefficient and wear resistance have been substantially increased by ceramic addition [7]. Among the extraordinary physical and mechanical properties of boron carbide is c-BN, which has the second highest hardness value following diamonds. In addition to this property, low density, high melting point and high wear resistance make this material attractive [8].

These elements, reinforced into metal matrix composites, may change the properties of these materials towards a better direction, and in this way, broaden their fields of application. In order for the properties of composites to be changed, carefully checking the size and reinforcement ratios provides various advantages $[9,10]$. The need for light and high-strength materials has been known since the invention of the airplane. As the strength and hardness of a material increase, the amount of material that is needed to carry a certain load, its dimensions, and therefore its mass, decrease. This provides several advantages, such as increased loads and improved fuel efficiency in planes and automobiles [11].

MMC are preferred in specific application areas due to the high modulus of elasticity, strength and better wear resistance than that of conventional alloys. Several studies have investigated the wear resistance of $\mathrm{Al}$ MMC strengthened by different reinforcement components $(\mathrm{SiC}$, $\mathrm{Al}_{2} \mathrm{O}_{3}, \mathrm{TiC}$ and $\mathrm{B}_{4} \mathrm{C}$ ), especially under dry sliding conditions [12]. Wear occurs at three stages. These are the initial, mild and severe stages. Wear rate and stages are related to the process temperature; and especially at a critical temperature, the wear mechanism varies based on the mild to severe wear in the MMC. Hard particles increase the transition temperature by approximately $40-50{ }^{\circ} \mathrm{C}$ [13].

Wear is a surface phenomenon that occurs by separation and displacement of material. As a result of weight continuing for a certain period of time, change occurs in dimensions. Due to all the mechanical components, the sliding or rolling contact needs to cause an amount of wear. The parts in question are ball-bearings, gears, gaskets, guides, piston rings, splines, brakes and clutches [14]. The wear behaviors of Aluminum matrix composites (AMC) are definitely dependent on the reinforcement particles, particle size and ratio. If the reinforcement particle is well-bonded to the matrix, the wear rate of the composite continuously increases [15-17].

The purpose of this study is to investigate the effects of the $5-15 \% \mathrm{~B}_{4} \mathrm{C}$ additions on the wear properties of the Aluminum matrix. Metallographic techniques were used for the characterization process. Wear tests on a disc and by disk were carried out on each sintered specimen with a $\mathrm{B}_{4} \mathrm{C}$. Characterization was performed by scanning electron microscopy (SEM) and X-ray. By conducting hardness and density tests, the mechanical properties of these specimens were examined. 


\section{RESEARCH METHODOLOGY}

\subsection{Materials and Preparation Techniques}

This study used $10 \mu \mathrm{m}$ pure aluminum powder particles reinforced with $\mathrm{B} 4 \mathrm{C}$ particles by $5 \%$ and $15 \%$ weight (wt.) and composites produced with this reinforcement. The materials that were subjected to the tests were produced with the powder metallurgy $(\mathrm{P} / \mathrm{M})$ technique. As the main matrix material, American-origin, atomized pure aluminum ( $\mathrm{Al}$ ) powders with $99.99 \%$ purity, $2.699 \mathrm{~g} / \mathrm{cm}^{3}$ density and $10 \mu \mathrm{m}$ nominal size produced by the firm Alfa Aesar, Johnson Matthey $\mathrm{GmbH} \& \mathrm{Co}$. were utilized, while American-origin boron carbide $\left(\mathrm{B}_{4} \mathrm{C}\right)$ particles with a density of $2.52 \mathrm{~g} / \mathrm{cm}^{3}$ and average sizes of 10-30 $\mu$ m produced by the firm Alfa Aesar, Johnson Matthey GmbH \& Co. KG were used as the reinforcement material.

\subsection{Characterization}

The powder morphologies and microstructures of sintered specimens were examined by using a scanning electron microscope (SEM, JEOL Ltd., JSM5910LV). The determination of the microstructural phases were performed by a Rigaku X-ray diffractometer by using $\mathrm{Cu} / \mathrm{K} \alpha$ radiation, $2^{\circ}$ beam angle, diffraction angle in the range of $10-85^{\circ}$, increments of $0.02^{\circ}$ and counting time of $1 \mathrm{~s}$. An Energy Dispersive Spectrometer (EDS, OXFORD Industries INCAx-sight 7274, (133-eV resolution) was also used for the analysis of the elements present in the microstructure.

\subsection{Production of Composites}

Aluminum matrix composite specimens were produced with the $\mathrm{P} / \mathrm{M}$ method by adding 5,10 , and $15 \mathrm{wt} . \%$ of $\mathrm{B}_{4} \mathrm{C}$ as reinforcement. Sample production by $-\mathrm{P} / \mathrm{M}$ is shown in Fig. 1.

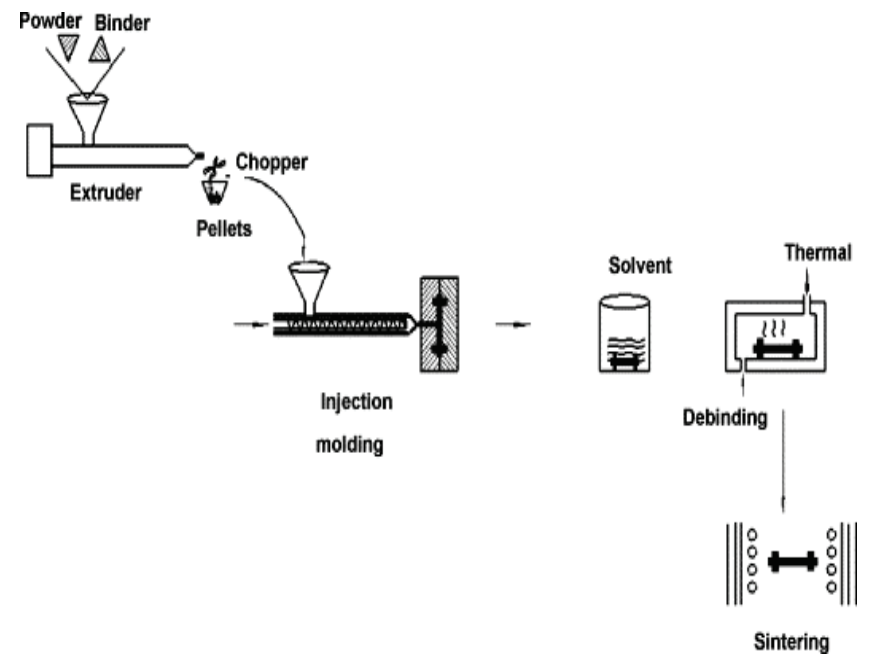

Figure 1 Fabrication stages of the B4C reinforced Al matrix composite [1]

During the production of the composites, $1 \%$ by weight acrowax binder and $5-15 \% \mathrm{~B}_{4} \mathrm{C}$ were mixed with aluminum particles. The mechanical alloying process was projected as approximately seven hours in an attrition mill in $500 \mathrm{ml}$ of ethanol. The ratio of the $\mathrm{Al} / \mathrm{B}_{4} \mathrm{C}$ composite powder to the main mass was 1:5, the rotational speed was $450 \mathrm{rpm}$, and the diameter of the stainless-steel ball that was used was $8 \mathrm{~mm}$. Sieving was carried out by 4 hours of drying at $50{ }^{\circ} \mathrm{C}$ as a result of mechanical alloying. The composite powder specimens that were obtained after the drying and sieving processes were easily pressed by Cold Isostatic Pressing (CIP) at $350 \mathrm{MPa}$ due to the ceramic behavior of $\mathrm{B}_{4} \mathrm{C}$. A pure argon environment was selected as the sintering atmosphere, and sintering was performed for 90 minutes. Metal aluminum experiences phase transformations at $600-650{ }^{\circ} \mathrm{C}$. As the objective was high strength, the sintering temperature was selected as $600-650^{\circ} \mathrm{C}$. The phase transition temperatures of aluminum with $\mathrm{B}_{4} \mathrm{C}$ and the phases that can emerge at different temperatures and ratios are shown in the phase diagram in Fig. 2 [18].
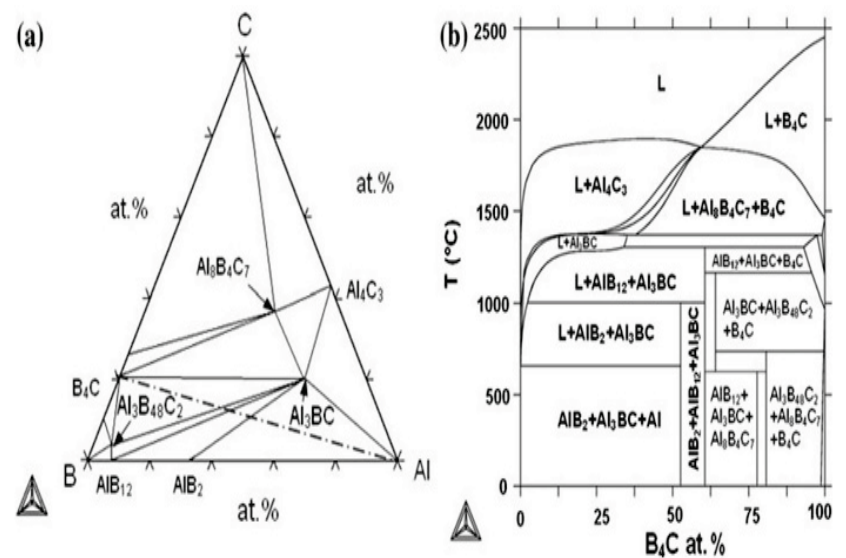

Figure 2 Al-B4C phase transition diagrams: a) Al - B - C isothermal cross-section at different temperatures, b) $\mathrm{Al}-\mathrm{B}_{4} \mathrm{C}$ isohypse phase diagram [19].

\subsection{Hardness and Density Experiments}

Mechanical properties of composite specimens were determined by a microhardness test. The tests were performed by a Future-Tech microhardness device (FM-700, Future Tech Corp.) using a load of $1000 \mathrm{~g}$. The density of samples was measured by the Archimedes method (Switzerland-Presciva XB 320 M).

\subsection{Metallographic Analysis}

The produced composite samples were grounded by using X120, X240, X500, X800 grit papers and followed by $\mathrm{Al}_{2} \mathrm{O}_{3}$ paste polishing. The polished samples were etched with a Kroll solution ( $3 \mathrm{~mL} \mathrm{HP}, 6 \mathrm{~mL} \mathrm{HNO}_{3}$ inside $100 \mathrm{~mL}$ $\mathrm{H}_{2} \mathrm{O}$ ). The microstructural analysis of specimens was performed by SEM.

\subsection{Wear Test}

Wear tests were carried out at room temperature without a lubricant on a standard pin-on-disk machine with a D2 tool steel plate constantly rotating with the hardness degree of 65 HRC as the counter-surface. For the wear test, the specimen 
pin was selected with the dimensions of $\varnothing 10 \times 10 \mathrm{~mm}$, and the wear surface was polished up to a roughness value of 0.159 $\mu \mathrm{m} R a$. The test was conducted in four replications to provide repeatability for each specimen. The disk surface was grounded, and a roughness value of $0.830 \mu \mathrm{m} R a$ was achieved. For all wear tests, the sliding rate, sliding distance and load were kept constant at $1.04 \mathrm{~m} / \mathrm{s}, 3000 \mathrm{~m}$ and $9.8 \mathrm{~N}$, respectively. All wear test specimens were carefully cleaned and dried. The specimens were cleaned with ethanol before and after the test to measure the loss of weight by a sensitivity of \pm 0.0001 grams. To achieve good replicability in wear results, at least four tests were carried out in each test condition [20]. Wear surfaces were imaged by using a highresolution SEM. The Pin On wear test was performed in the apparatus shown in Fig. 3.

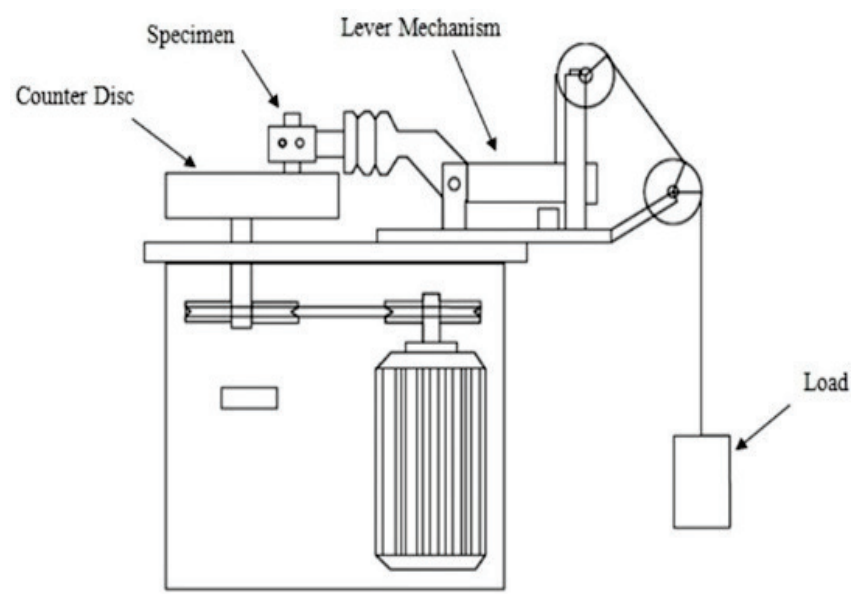

Figure 3 The scheme of a pin on a disc wear device

\section{RESEARCH DISCUSSION}

Images of the aluminum and boron carbide powders taken by the scanning electron microscope are shown in Fig. 4. As seen here, the aluminum powders that were used were not completely spherical, and the average grain size distribution was around $10 \mu$.
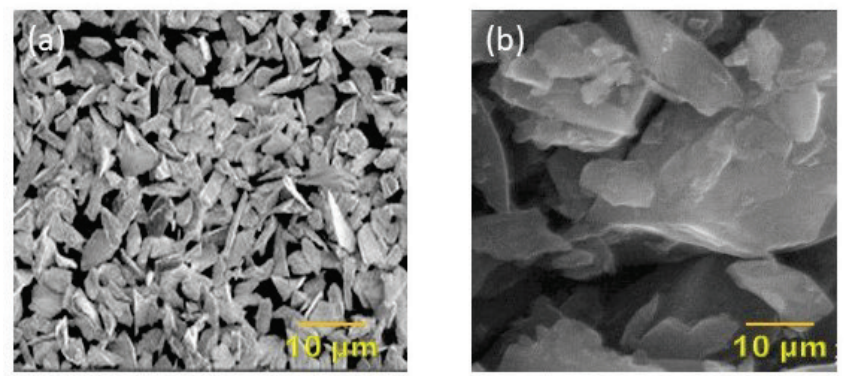

Figure 4 SEM images of the $\mathrm{B}_{4} \mathrm{C}$ and $\mathrm{Al}$ powders a) $\mathrm{Al}$ and b) $\mathrm{B}_{4} \mathrm{Cl}$

After the process of specimen preparation, the same magnification rate was used for all composite specimens that were prepared. The SEM images obtained from the flat crosssections of the $\mathrm{Al} / \mathrm{B} 4 \mathrm{C}$ composite specimens may be seen in Fig. 5. The images clearly show the homogenous distribution of $\mathrm{Al}$ with $\mathrm{B}_{4} \mathrm{C}$ based on the reinforcement rate especially in the specimens with low reinforcement rates and the phases aluminum showed with $\mathrm{B}_{4} \mathrm{C}$. There were also grey and darker areas in the structure. The grey areas corresponded to the carbide structures that formed, while the darker ones corresponded to the zone where porosity was occasionally intense with increased $\mathrm{B}_{4} \mathrm{C}$ amounts. The density and hardness values significantly increased by increased the sintering temperature especially in the specimen with a $15 \%$ $\mathrm{B}_{4} \mathrm{C}$. As seen here, $\mathrm{Al}_{3} \mathrm{BC}$ were found only in the grey areas. The grey area increased optimally based on the increased ratio of $\mathrm{B}_{4} \mathrm{C}$.
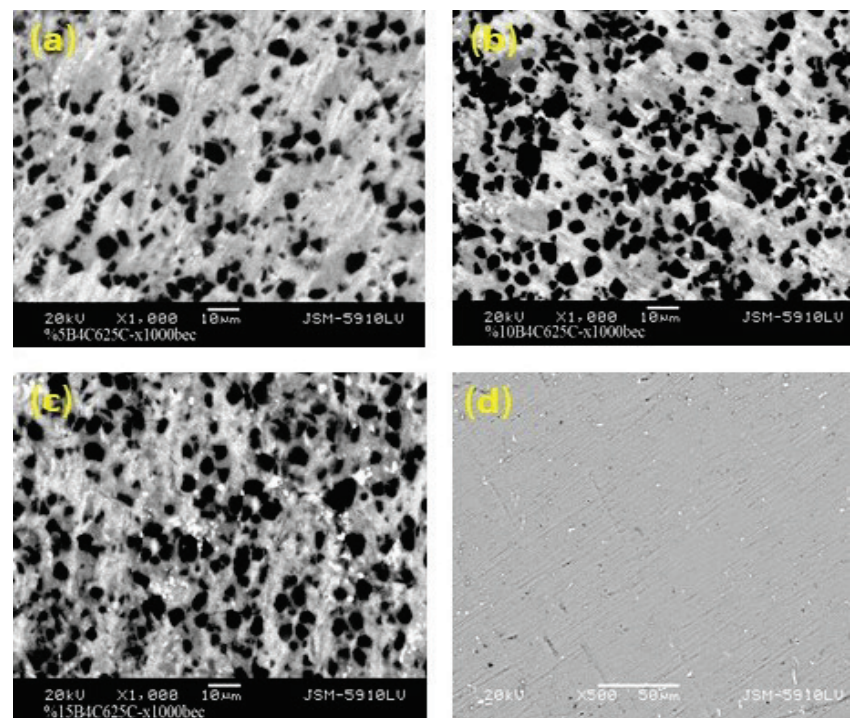

Figure $5 \mathrm{Al} / \mathrm{B}_{4} \mathrm{C}$ composites sintered at $650{ }^{\circ} \mathrm{C}$ (a) $5 \% \mathrm{Al} / \mathrm{B}_{4} \mathrm{C}$ reinforced $\mathrm{MMC}$, (b) $10 \% \mathrm{Al} / \mathrm{B}_{4} \mathrm{C}$ reinforced $\mathrm{MMC}$ (c) $15 \% \mathrm{Al} / \mathrm{B}_{4} \mathrm{C}$ reinforced $\mathrm{MMC}$ with SEM photographs of different reinforced materials

The purpose of the XRD analysis was to examine the various phases and reaction products in the $\mathrm{Al} / \mathrm{B}_{4} \mathrm{C}$ composites. As seen in Fig. 6, in the XRD characterization examination on the pure aluminum and $\mathrm{B}_{4} \mathrm{C}$ powders, the peak belonging to the aluminum powder was seen at 38.70, the secondary peak was seen at 44.80 , and similarly, the peaks belonging to the $\mathrm{B}_{4} \mathrm{C}$ appeared at 28.90 and 38.40, respectively.
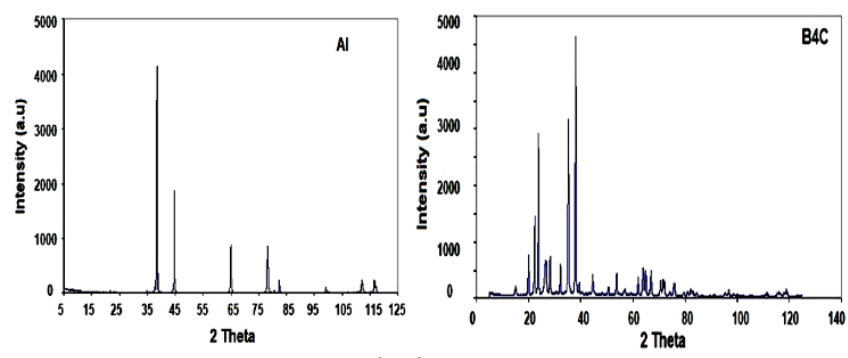

Figure 6 XRD pattern of $B_{4} C$ and pure Aluminum powders

The XRD pattern results show the density peaks of $\mathrm{Al}$, $\mathrm{B}_{4} \mathrm{C}, \mathrm{Al}_{2} \mathrm{~B}$ and $\mathrm{Al}_{3} \mathrm{BC}$ (Fig. 7). The $\mathrm{AlB}_{2}$ and $\mathrm{Al}_{3} \mathrm{BC}$ phases formed at the interface between the main matrix aluminum and the reinforcement $\mathrm{B}_{4} \mathrm{C}$. The presence of the $\mathrm{AlB}_{2}$ phase was relatively low [21]. The XRD results showed a more homogenous mixture with the $15 \% \mathrm{Al} / \mathrm{B}_{4} \mathrm{C}$ composite in comparison to the other reinforcement rates. The increase in 
reinforcement increased the peak magnitude of the composite.

As a result of $\mathrm{B}_{4} \mathrm{C}$ reinforcement, in the $\mathrm{XRD}$ characterization analysis of the $\mathrm{Al} / \mathrm{B} 4 \mathrm{C}$ composite material produced with the highest reinforcement ratio of $15 \%$, aluminum metal powders showed the highest peaks on the (111) and (200) planes, while $\mathrm{B}_{4} \mathrm{C}$ ceramic powders showed the highest peaks on the (104) and (021) planes. In the XRD analysis of the $\mathrm{Al} / \mathrm{B}_{4} \mathrm{C}$ composite specimen, it was very clearly observed that, as the $\mathrm{B}_{4} \mathrm{C}$ ratio increased, both peak magnitudes and peak areas noticeably increased for the $\mathrm{B}_{4} \mathrm{C}$ peaks [22].

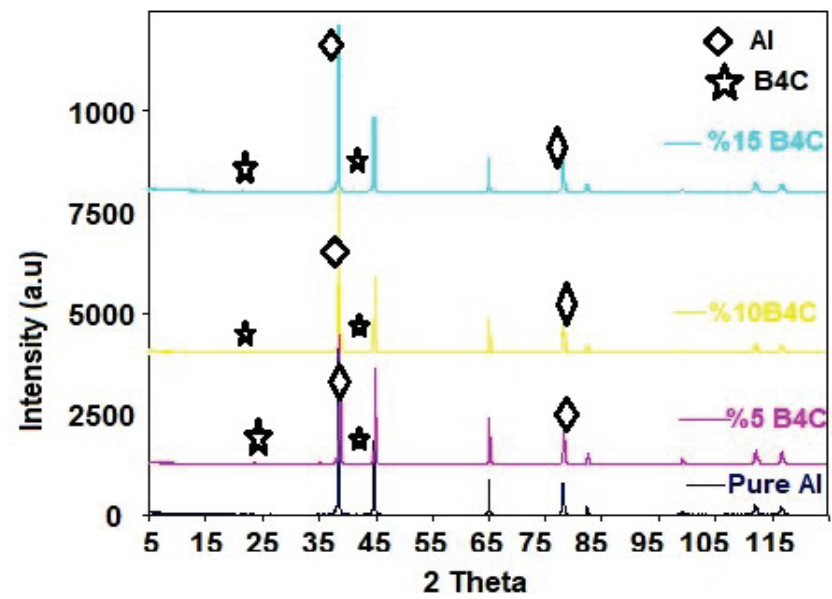

Figure $7 \mathrm{XRD}$ pattern of different $\%$ content $\mathrm{B}_{4} \mathrm{C}$ composites in the Al Matrix

As seen in Table1, the highest peak was observed at the $15 \%$ reinforcement ratio of $\mathrm{Al} / \mathrm{B} 4 \mathrm{C}$.

Table $1 \mathrm{XRD}$ peak areas of $\mathrm{Al} / \mathrm{B}_{4} \mathrm{C}$ composite specimens reinforced at different ratios

\begin{tabular}{|c|c|c|}
\hline Material & 2 Theta Angle $\left(38.4^{\circ}\right)$ & 2 Theta Angle $\left(28.9^{\circ}\right)$ \\
\hline $5 \% \mathrm{~B}_{4} \mathrm{C}$ & 2.32 & 0.58 \\
\hline $10 \% \mathrm{~B}_{4} \mathrm{C}$ & 2.74 & 1.03 \\
\hline $15 \% \mathrm{~B}_{4} \mathrm{C}$ & 4.16 & 1.41 \\
\hline
\end{tabular}

The densities of the produced $\mathrm{Al} / \mathrm{B}_{4} \mathrm{C}$ specimens were measured. They were found to be in agreement with the literature as they vary in the range of $95 \%$ to $97.5 \%$. The main reason for this different ratio was that while $\mathrm{B}_{4} \mathrm{C}$ has a low density, the $\mathrm{B}_{4} \mathrm{C}$ rate increased, and porosity was encountered. Equation 1 shows the density calculations.

$C_{\mathrm{R}}=\frac{V_{\mathrm{L}}}{V_{\mathrm{C}}}=\frac{\rho_{\mathrm{G}}}{\rho_{\mathrm{A}}}$.

In Eq. (1), $V_{\mathrm{L}}$ is the volume of the loose powder, $V_{\mathrm{C}}$ is the volume of the compressed powder, $\rho_{\mathrm{G}}$ is the green density, and $\rho_{\mathrm{A}}$ is the apparent density.

The lowest density of the $\mathrm{Al} / \mathrm{B}_{4} \mathrm{C}$ composite specimens was calculated in the specimen with a $15 \%$ reinforcement as the highest ratio of $\mathrm{B}_{4} \mathrm{C}$ by weight. Fig. 8 shows the density values of the composites that were produced by different ratios of reinforcements.

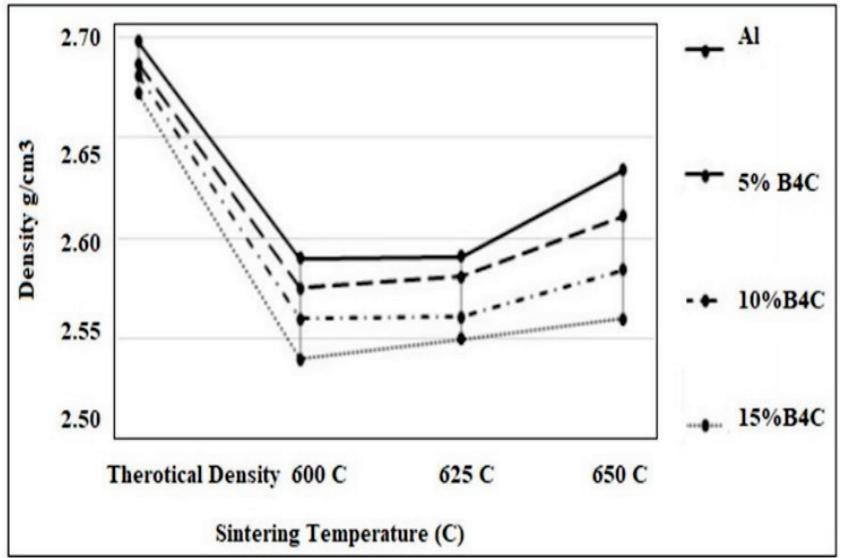

Figure 8 Density values of the specimens produced by a $5-15 \% B_{4}$ C reinforcement

It was observed that the densities of the produced specimens decreased with the increase in the ratio of reinforcement, but they increased based on sintering temperatures. In the SEM image given in Fig. 9, it is seen that the boron carbide particles were homogenously distributed, and there was no grain enlargement or flocculation.

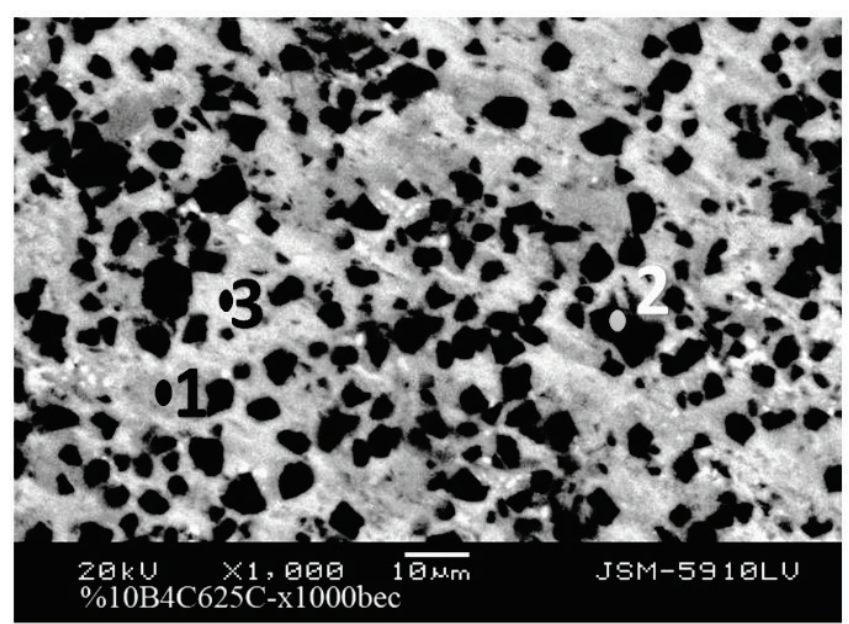

Figure $9 \mathrm{Al}, \mathrm{B}_{4} \mathrm{C}, \mathrm{Al}_{2} \mathrm{BC}$ phase and porosity image of a $15 \%$ reinforced $\mathrm{Al} / \mathrm{B}_{4} \mathrm{C}$ composite sample

Elemental analysis of a $10 \% \mathrm{~B}_{4} \mathrm{C}$ reinforced composite sample is shown in Tab. 2.

Table 2 Elemental analysis of a $10 \% \mathrm{Al} / \mathrm{B}_{4} \mathrm{C}$ composite specimen

\begin{tabular}{|c|c|}
\hline Point & Material \\
\hline 1. & $\% 70.04 \mathrm{Al}+\% 18.84 \mathrm{~B}+\% 11.12 \mathrm{C}$ \\
\hline 2. & $\% 100 \mathrm{~B}_{4} \mathrm{C}$ \\
\hline 3. & $\% 100 \mathrm{Al}$ \\
\hline
\end{tabular}

The tested specimens were the $\mathrm{Al} / \mathrm{B}_{4} \mathrm{C}$ metal matrix composite specimens produced by $\mathrm{P} / \mathrm{M}$ by reinforcing $\mathrm{B}_{4} \mathrm{C}$ into the $\mathrm{Al}$ matrix at different ratios. The expectation from the produced specimens as a result of the experiment was that density would reach the desired level in parallel with the literature $(97.5 \%)$. The high sintering temperature that was applied and increasing $\mathrm{B}_{4} \mathrm{C}$ ratio [24].

Hardness test was applied on the composite specimens that were produced and metallographically prepared. In this 
test, in order to make sure that the compressive trace covered both the matrix and the reinforcement material, 10 consecutive measurements were made with frequent intervals $(150 \mu)$, and the results were obtained by taking the average of the outcomes. The hardness values that were obtained represent the average hardness of the $\mathrm{Al} / \mathrm{B} 4 \mathrm{C}$ composites. Fig. 10 shows the results of hardness measurements.

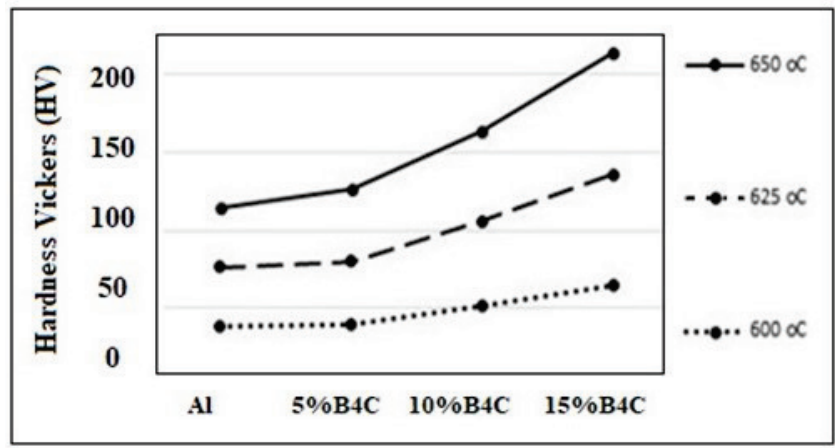

Figure 10 The hardness values of the $A / / B_{4} C$ composite specimens produced by a $5-15 \% \mathrm{~B}_{4} \mathrm{C}$ reinforcement

The increased ratio of $\mathrm{B} 4 \mathrm{C}$ by weight raised the hardness of the composite. Differences were observed in the measured hardness values of the specimens with different reinforcement ratios. The hardness values of composite materials increased due to the $\mathrm{AlB}_{2}$ and $\mathrm{AL}_{3} \mathrm{BC}$ phases formed by $\mathrm{B}_{4} \mathrm{C}$ and aluminum. As opposed to this, low hardness values were occasionally also observed, which may be explained by encountering the pure $\mathrm{Al}$ matrix in addition to increased $\mathrm{B}_{4} \mathrm{C}$ amounts [25].

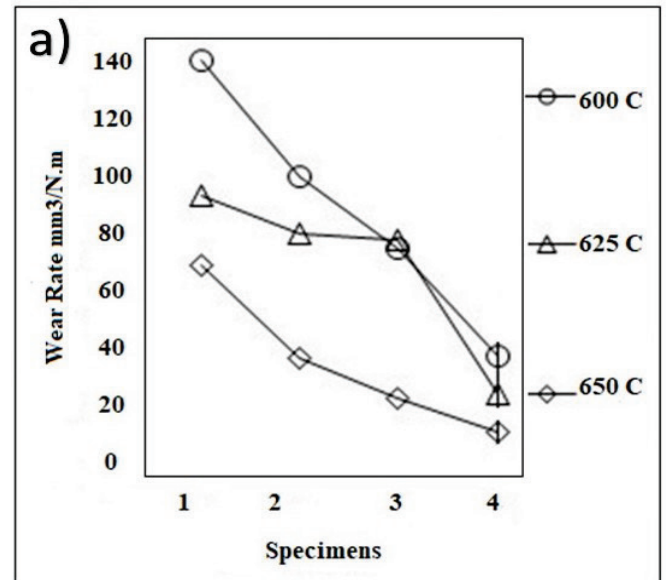

Figure 11 Wear test results of Aluminum and (5-15\% Al/ $\mathrm{B}_{4} \mathrm{C}$ composites; $\left.\mathrm{a}\right)$ Wear rate $\left.\mathrm{b}\right)$ Wear resistance

Since the load that was applied was constant at $10 \mathrm{~N}$, for observing material losses, the ratio of $\mathrm{B}_{4} \mathrm{C}$ by weight was adjusted to 5,10 and 15\%. As seen in Fig. 11, as the $\mathrm{B}_{4} \mathrm{C}$ percentage ratio in the alloy increased, the wear rate of the specimens decreased. As the sliding distance increased, wear loss increased, and wear rate decreased. While the wear performance of the pure aluminum and the composite material with a $5 \% \mathrm{~B}_{4} \mathrm{C}$ reinforcement was especially poor, with the $\mathrm{B}_{4} \mathrm{C}$ ratio increased up to $10-15 \%$, it was determined
Some researchers stated that the strength of the material increased with the increased $\mathrm{B}_{4} \mathrm{C}$ reinforcement ratios. As the reason behind this, they asserted that the carbon content of the structure and hardness values increased linearly. The carburized phase had higher surface tensions in comparison to other specimens and provided an increase in hardness [26]. Based on the assumption in question, the aluminum boride $\left(\mathrm{AlB}_{3}\right)$ and aluminum-rich boride-carbide $\left(\mathrm{Al}_{3} \mathrm{BC}\right)$ structures that formed on the surface layer that was subjected to wear led to an increase in wear resistance.

Composite specimens that were produced in the same way as the surfaces which were metallographically prepared were subjected to wear tests. Different wear was calculated as both the covered path and loss of weight. The wear rate was calculated by using the following equation.

$W_{\mathrm{S}}=\frac{D_{\mathrm{m}}}{q \cdot L \cdot F_{\mathrm{N}}} \times 10^{9}$

In Eq. (2), $W_{\mathrm{S}}$ is the wear rate in $\mathrm{mm}^{3} / \mathrm{Nm}, D_{\mathrm{m}}$ is the mass lost in the test specimens during $N$ revolutions in $\mathrm{g}, q$ is the density of the test materials in $\mathrm{g} / \mathrm{cm}^{3}, L$ is the total sliding distance in $\mathrm{m}$, and $F_{\mathrm{N}}$ is the normal force on the pin in $\mathrm{N}$.

The total sliding distance was monitored by an automated recording device. The worn surfaces of all specimens were examined by using SEM. The constant weight of $10 \mathrm{~N}$ was used in the wear tests. As shown in Fig. 11 , wear tests were carried out at three different sintering temperatures and three different compositions. In the study, an analysis was carried out by considering the loss of weight, wear resistance and wear rates [28].

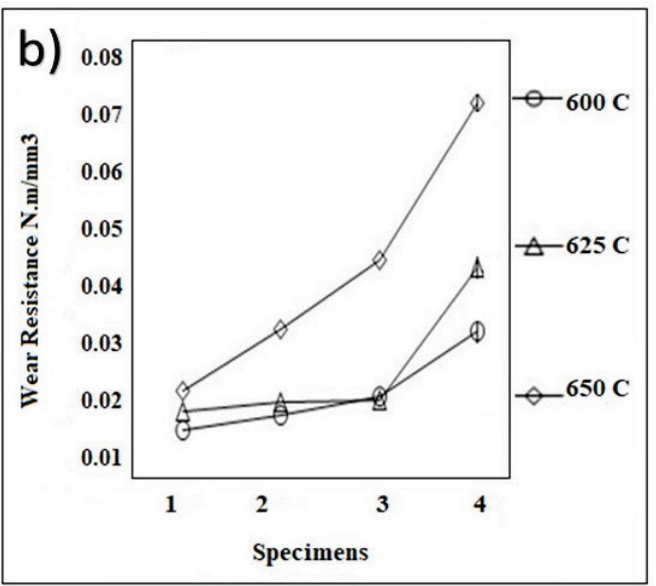

that the wear loss decreased noticeably. The lowest material loss was observed in the composite containing $15 \% \mathrm{~B}_{4} \mathrm{C}$. Improved wear resistance may be attributed to the presence of the hard $\mathrm{Al}_{3} \mathrm{BC}$ phase and $\mathrm{B}_{4} \mathrm{C}$ in the composite. The $15 \%$ ratio of $\mathrm{B}_{4} \mathrm{C}$ by weight increased the observed wear loss. This may be explained by the higher ratio of the $\mathrm{Al}_{3} \mathrm{BC}$ phase in the composite. In further paths, it was observed that wear resistance decreased probably because of the decreased capacity for the load of the Al matrix to be effectively 
transferred to the $\mathrm{B}_{4} \mathrm{C}$ reinforcement. During wear tests, as the $\mathrm{Al}_{2} \mathrm{~B}$ and $\mathrm{Al}_{3} \mathrm{BC}$ interface phases make fracturing difficult, their load carrying capacities increase. For this reason, the bonding between the reinforcement and the matrix is affected positively, and the wear resistance of the material increases. In addition to this, in general, improved wear resistance in composite specimens was attributed to the synergistic effect of the unique properties of $\mathrm{B}_{4} \mathrm{Cs}$ and the hard Al3BC interface product [29].

The SEM images of the worn specimen surfaces that were tested under $10 \mathrm{~N}$ of an applied force in dry friction conditions are shown in Fig. 12(a) and Fig. 12(b) respectively for the $\mathrm{B} 4 \mathrm{C}$ reinforcement content ratios of $5 \%$ and $15 \%$.
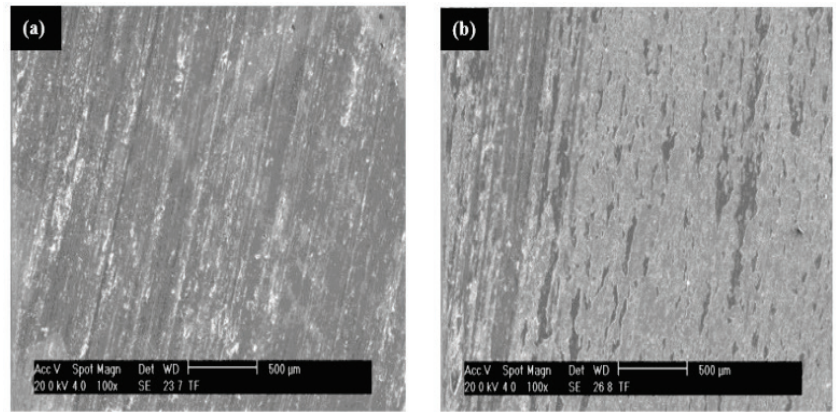

Figure 12 Worn surfaces of aluminum matrix composites: (a) $5 \% \mathrm{~B}_{4} \mathrm{C}$ and (b) $15 \%$ $\mathrm{B}_{4} \mathrm{C}$ content

Larger mean roughness shows the irregularity of the $\mathrm{Al}_{2} \mathrm{BC}$ phase and may contribute to the presence of stress concentrations on the surface. With the applied force, as the ratio of the $\mathrm{B}_{4} \mathrm{C}$ reinforcement increased in the composites containing different ratios (Fig. 12(a) and Fig. 12(b), this prevented the progressive magnitude of the adhesive wear. This supported the previous proposition on the strong interface between the reinforcement and the matrix and the metallurgical bonding with a higher ratio of the $\mathrm{B}_{4} \mathrm{C}$ reinforcement.

A recent study suggested that wear behaviors are formed by metal residues that are produced and/or transferred during the sliding of the Al alloy. These were sintered on sanded, mixed, compressed and sometimes worn surfaces. During these activities, metal shavings react with oxygen, and this may be the cause of the oxide layers observed on worn specimen surfaces. In addition to this [28], the results of the study, as opposed to those reported by other researchers [2930], stated that oxidative wear takes place during the dry sliding of an $\mathrm{Al}$ alloy in normal loads that are applied low. While it was supported by a relevant literature study that the adhesive wear mechanism changed in composites with a 10 and $15 \%$ reinforcement, adhesive wear took place in the $5 \%$ $\mathrm{B}_{4} \mathrm{C}$-reinforced materials. Due to this, in parallel to the highest hardness values, the highest wear resistance was obtained with the $15 \% \mathrm{Al} / \mathrm{B}_{4} \mathrm{C}$ composites. This situation shows that reinforcement elements need to be at certain ratios. As expected, production of the $\mathrm{Al}$ MMCs with $\mathrm{B}_{4} \mathrm{C}$ reinforcement was effective in improving wear resistance and friction characteristics. In the literature review, why composites with low ratios of reinforcements have lower wear resistance and why wear resistance increases by increased ratios of reinforcements were very clearly explained.

\section{CONCLUSION}

This study researched the density, hardness, microstructure and wear behaviors of composite $\left(\mathrm{Al} / \mathrm{B}_{4} \mathrm{C}\right)$ specimens that were produced by different reinforcement ratios with $\mathrm{Al} / \mathrm{B}_{4} \mathrm{C}$. According to the findings of this study, the density of specimens got closer to the theoretical density, the desired levels (96-97.5\%), by increased boron carbide contents.

As a result of the XRD analysis on the $15 \% \mathrm{Al} / \mathrm{B}_{4} \mathrm{C}$ composite that was prepared by mechanical alloying for 90 minutes in an attrition mill, it was determined that the peaks which occurred at different theta angles corresponded to the $\mathrm{B}_{4} \mathrm{C}$ particles in the rhombohedral structure, and the increased $\mathrm{B}_{4} \mathrm{C}$ content led to an increase in the peak area and magnitude of this reinforcement.

The SEM images showed that most $\mathrm{B}_{4} \mathrm{C}$ powders were homogenously distributed into the main matrix, and there was no separation at a certain zone. In addition to this, by increased $\mathrm{B}_{4} \mathrm{C}$ ratios, the presence of the porous structure caused by reinforcement powders was observed very rarely.

By increasing the ratio of the $\mathrm{B}_{4} \mathrm{C}$ by weight (up to $15 \%$ ) and different sintering temperatures, especially the temperature of $650{ }^{\circ} \mathrm{C}$, increased the hardness of the metal matrix composite.

With the effects of different sintering temperatures in addition to the increased reinforcement ratio, there were decreases in weight losses and wear rates, while there was an increase in wear resistance.

The aforementioned increase occurred due to the aluminum-rich boride-carbide $\left(\mathrm{Al}_{3} \mathrm{BC}\right)$ phase that formed in the matrix as a result of sintering. Increased hardness with the addition of $\mathrm{B}_{4} \mathrm{C}$ may be attributed to the effect of dispersion strengthening. In the wear test that was carried out by also referring to the studies in literature, it was observed that the $\mathrm{B}_{4} \mathrm{C}$ reinforcement was positively effective on the wear resistance of the material, and it was thought to improve wear resistance.

\section{Acknowledgment}

This work was supported by the Scientific Research Project Program of Marmara University (FEN-K-0703170107).

\section{REFERENCES}

[1] German, R. M. (2005). Powder Metallurgy and Particulate Materials Processing, Metal powder industry federation, Princeton. Sintering science, 38(1), 95, 522. https://doi.org/10.2298/SOS0601095U

[2] Panda, A., Dobransky, J., Jančik, M., Pandova, İ., \& Kačalova, M. (2018). Advantages and effectiveness of the powder metallurgy in manufacturing technologies. Metalurgija, 57(4), $353-356$. 
[3] Topcu, I. (2018). Karbon Nanotüp Takviyeli Aluminyum Matriksli AlMg/KNT Kompozitlerinin Mekanik Davranışlarının İncelenmesi, Journal of Graduate School of Natural and Applied Sciences, 4(1), 99-109. https://doi.org/10.28979/comufbed.359796

[4] Thangavel, S., Murugan, M., \& Zeelanbasha, N. (2019). Investigation of cutting force in end milling of al/n-tic/mos 2 sintered nano composite. Metalurgija, 58(3-4), 251-254.

[5] Akramifard, M. S., Sabbaghian, M., \& Esmailzadeh, M. (2014). Microstructure and mechanical properties of $\mathrm{Cu} / \mathrm{SiC}$ metal matrix composite fabricated via friction stir processing. Materials \& Design (1980-2015), 54, 838-844.

https://doi.org/10.1016/j.matdes.2013.08.107

[6] Prakash, J. U., Ananth, S., Sivakumar, G., \& Moorthy, T. V. (2018). Multi-Objective Optimization of Wear Parameters for Aluminium Matrix Composites (413/B4C) using Grey Relational Analysis. Materials Todays, 5(2), 7207-7216. https://doi.org/10.1016/j.matpr.2017.11.387

[7] Shin, S. E. \& Bae, D. H. (2018). Fatigue behavior of Al2024 alloy-matrix nanocomposites reinforced with multi-walled carbon nanotubes. Compos. Part B Eng. 134, 61-68. https://doi.org/10.1016/j.compositesb.2017.09.034

[8] Canakci, A. (2014). Synthesis of novel CuSn10-graphite nanocomposite powders by mechanical alloying. Micro \& Nano Letters, 9(2), 109-112. https://doi.org/10.1049/mnl.2013.0715

[9] Manjunatha, B., Niranjan, H. B., \& Satyanarayana, K. G. (2018). Effect of amount of boron carbide on wear loss of Al6061 matrix composite by Taguchi technique and Response surface analysis. Materials Science and Engineering, 376. https://doi.org/10.1088/1757-899X/376/1/012071

[10] Liu, Z. Y., Xu, S. J., Xiao, B. L., Xue, P., Wang, W. G., \& Ma, Z. Y. (2012). Effect of ball-milling time on mechanical properties of carbon nanotubes reinforced aluminum matrix composites. Compos. Part Appl. Sci. Manuf. 43, 2161-2168. https://doi.org/10.1016/j.compositesa.2012.07.026

[11] Al-Aqeeli, N., Abdullahi, K., Suryanarayana, C., Laoui, T., \& Nouari, S. (2013). Structure of mechanically milled CNTreinforced Al-alloy nanocomposites. Mater. Manuf. Process. 28, 984-990

[12] Canakci, A. (2014). Microstructure and Abrasive Wear Behavior of CuSn10-Graphite Composites Produced by Powder Metallurgy. Powder Metallurgy and Metal Ceramics, 53(5-6), 275-287. https://doi.org/10.1007/s11106-014-9614-2

[13] Akbulut, H. \& Kara, Y. (2017). Karbon takviyeli karbon nanotüp katkılı epoksi kompozit helisel yayların mekanik davranışları. Journal of the Faculty of Engineering and Architecture of Gazi University, 32. https://doi.org/10.17341/gazimmfd.322166

[14] Firat, F. K. \& Eren, A. (2015). Investigation of FRP Effects on Damaged Arches in Historical Masonry Structures. Journal of the Faculty of Engineering \& Architecture of Gazi University, 30. https://doi.org/10.17341/gummfd.46980

[15] Baradeswaran, A., Perumal, N. E., Selvakumar, R., \& Franklin, I. R. (2014). Experimental investigation on mechanical behaviour, modelling and optimization of wear parameters of B4C and graphite reinforced aluminium hybrid composites. Materials \& Design, 63, 620-632. https://doi.org/10.1016/j.matdes.2014.06.054

[16] Varol, T. \& Canakci, A. (2013). Effect of particle size and ratio of $\mathrm{B} 4 \mathrm{C}$ reinforcement on properties and morphology of nanocrystalline A12024-B4C composite powders. Powder Technology, 246, 462-472. https://doi.org/10.1016/j.powtec.2013.05.048

[17] Sathiskumar, N. M., Dinaharan, I., \& Vijay, S. J. (2014).
Fabrication and Characterization Of $\mathrm{Cu} / \mathrm{B} 4 \mathrm{C}$ Surface Dispersion Strengthened Composite Using Friction Stir Processing. Archives of Metallurgy and Materials, 59(1), 8387. https://doi.org/10.2478/amm-2014-0014

[18] Topcu, İ., Güllüoğlu, A. N., Bilici, M. K, \& Gülsoy, H. Ö. (2018). Investigation of wear behavior ofTi-6Al-4V/CNT composites reinforced with carbon nanotubes. Journal of the Faculty of Engineering and Architecture of Gazi University. https://doi.org/10.17341/gazimmfd.460542

[19] Arslan, G. \& Kalemtaş, A. (2009). Processing of silicon carbide-boron carbide-aluminium composites, Journal of the European Ceramic Society, 29,473-480. https://doi.org/10.1016/j.jeurceramsoc.2008.06.007

[20] Rashad, M., Pan, F., Yu, Z., Asif, M., Lin, H. \& Pan, R. (2015). Investigation on microstructural, mechanical and electrochemical properties of aluminum composites reinforced with graphene nanoplatelets. Prog. Nat. Sci. Mater. Int. 25. 460-470. https://doi.org/10.1016/j.pnsc.2015.09.005

[21] Canute, X. \& Majumder, M. C. (2018). Investigation of tribological and mechanical properties of aluminium boron carbide composites using response surface methodology and desirability analysis. Industrial Lubrication and Tribology,70, 301-315. https://doi.org/10.1108/ILT-01-2017-0010

[22] Topcu, I., Gulsoy, H. Ö., Kadioglu, N., \& Gulluoglu, A. N. (2009). Processing and Mechanical properties of B4C Reinforced Al Matrix Composites. Journal of Alloys and Compounds, 482, 516-521. https://doi.org/10.1016/j.jallcom.2009.04.065

[23] Turan, M. E., Sun, Y., Aydin, F., Zengin, H., Turen, Y., \& Ahlatci, H. (2018). Effects of carbonaceous reinforcements on microstructure and corrosion properties of magnesium matrix composites. Mater. Chem. Phys. 218, 182-188. https://doi.org/10.1016/j.matchemphys.2018.07.050

[24] Gülsoy, H. Ö., Bilici, M. K., Bozkurt, Y., \& Salman, S. (2007). Enhancing the wear properties of iron based powder metallurgy alloys by boron additions. Materials and Design, 28, 22552259. https://doi.org/10.1016/j.matdes.2006.05.022

[25] Adegbenjo, A. O., Babatunde, A., \& Obadele, B. A. (2018). Densification, hardness and tribological characteristics of MWCNTs reinforced Ti6Al4V compacts consolidated by spark plasma sintering. Journal of Alloys and Compounds, 749, 818-833. https://doi.org/10.1016/j.jallcom.2018.03.373

[26] Saheb, N., Khalil, A., Hakeem, A., Al-Aqeeli, N., Laoui, T., \& Qutub, A. (2014). Spark plasma sintering of CNT reinforced Al6061 and A12124 nanocomposites. Journal of Composite Materials, 18.

[27] Wang, F. C., Zhang, Z. H., Sun, Y. J., Liu, Y., Hu, Z. Y., Wang, H., Korznikov, A. V., Korznikova, E., Liu, Z. F. \& Osamu, S. (2015). Rapid and low temperature spark plasma sintering synthesis of novel carbon nanotube reinforced titanium matrix composites. Carbon, 95, 396-407. https://doi.org/10.1016/j.carbon.2015.08.061

[28] Leila, M. \& Mohammad, T. V. (2017). Solid Phase Extraction and Determination of Methyldopa in Pharmaceutical Samples Using Molecularly Imprinted Polymer Grafted Carbon Nanotubes. J. Chem. Soc. Pak, 39, 446.

[29] Kumar, L., Alam, S. N., \& Sahoo, S. K. (2017). Mechanical properties, wear behavior and crystallographic texture of $\mathrm{Al}-$ multiwalled carbon nanotube composites developed by powder metallurgy route. J. Compos. Mater. 51, 1099-1117. https://doi.org/10.1177/0021998316658946

[30] Bastwros, M. M., Esawi, A. M., \& Wifi, A. (2013). Friction and wear behavior of Al-CNT composites. Wear, 307, 164173. https://doi.org/10.1016/j.wear.2013.08.021 
Authors' contacts:

İsmail Topcu, Assistant Professor, PhD

Alanya Aladdin Keykubat University,

College of Engineering, Department of Metallurgy and Materials,

07450 Kestel Alanya Antalya, Turkey

E-mail: ismail.topcu@alanya.edu.tr 